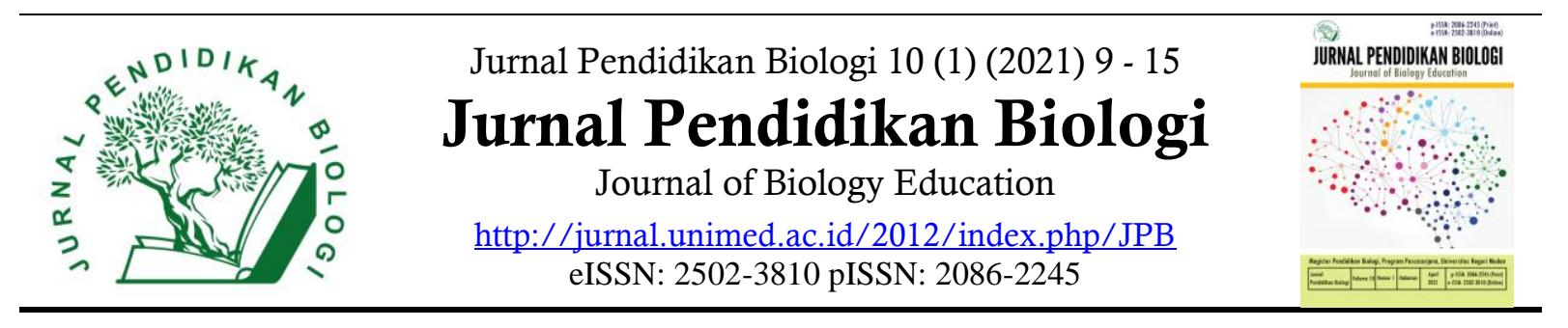

\title{
The Profile of Collaboration Skills of Science Students in SMA Negeri 07 Surakarta
}

\author{
Anita Rahmawati Sutanto, Astried Pascafitri Harenda, Myanda Azkya Arsyi, Suci Nur \\ Cahyani, Baskoro Adi Prayitno
}

Biology Education Study Program, Faculty of Teacher Training and Education, Sebelas Maret University, Jalan Ir. Sutami No. 10A, Surakarta, 57126, Central Java, Indonesia

\section{ARTICLE INFO}

\section{Article History}

Received 26 December 2020

Revised 10 April 2021

Accepted 27 May 2021

Published 3 June 2021

\section{Keywords:}

Biology Learning,

Collaboration Skills,

Senior High School Research

\begin{abstract}
Collaboration skills between students are needed to optimize learning outcomes. Collaboration skills in learning can allow students to exchange information and ideas with their friends, therefore can increasing students' understanding of a material. This study aims to determine the collaboration skills and find out the differences of collaboration skills on science students grade X, XI, and XII in SMA N 07 Surakarta. This study used survey method. Population of this study included all students of grade X, XI, XII, in total 600 students. Stratified proportional random sampling was used as sampling technique with a sample of 20 students at each grade. Student collaboration skills are measured using questionnaires. Data analysis used quantitative description analysis and ANOVA. The results of the study showed that the profile of the X, XI and XII science students' collaboration skills in SMA N 07 Surakarta was in the range of $70-74 \%$ or in the high category. There is no difference in the collaboration skills of science students of grade X, XI, and XII $(\alpha=0.412>0.05)$.
\end{abstract}

Copyright $\odot 2021$ Medan State University. This Open Access article is licensed under CC-BY-4.0 (https://creativecommons.org/licenses/by/4.0)

\section{How to Cite}

Sutanto, A. R., Harenda, A. P., Arsyi, M. A., Cahyani, S. N. \& Prayitno, B. A. (2021). The Profile of Collaboration Skills of Science Students in SMA Negeri 07 Surakarta. Jurnal Pendidikan Biologi, 10(1), 9-15.

\section{INTRODUCTION}

Education is a process that every individual needs to balance their development in society. In essence, humans are social creatures where they need help and collaboration with other people to achieve their life goals. Education can be used to develop the skills of each individual to support their development in the social environment (Indy, et al., 2019). One of the skills that must be possessed by every individual is collaboration. This is because collaboration skills involve individuals to interact with each other in order to thrive (Khoiriah, 2016).
Apart from social life, collaboration skills must be implemented in the realm of education, especially in learning activities. The existence of collaboration skills can help students to optimize learning outcomes. This is because basically a learning community shows better learning outcomes than individuals who learn individually (Hamid \& Sholeh, 2011). Collaboration in learning allows students to exchange ideas, information, and knowledge with their peers. In addition, the existence of collaboration can increase self-confidence in students, so that collaboration can optimize students' understanding of a material (Rosita \& Leonard, 2015). 
Collaboration between students needs to be trained by the teacher in learning activities (Kusuma, 2018). Teachers can get used to using multi-directional communication which not only involves dynamic interactions between teachers and students but also involves dynamic interactions between one student and another (Wijaya, et al., 2016). Multi-directional communication learning can foster a variety of positive attitudes in students, such as training students to appreciate diversity of opinions, and to understand individual differences (Putri, et al., 2018).

The results of the 2012 NACE (National Association of Colleges and Employers) survey on the quality of human resources (Human Resources) were, respectively; communication skills, collaboration skills, interpersonal skills, ethics, motivation, GPA, leadership, and entrepreneurial skills. The survey results show that the ability in academics only ranks 17th (Turiman, et al., 2012). Meanwhile, every student has an important ability to collaborate as a provision for facing his life in the future.

In fact, not all students have good collaboration skills. The low level of collaboration skills in students is reflected in the fact that student learning tends to be individualistic, there is less tolerance among students, and the value of togetherness that is owned by students tends to be low (Rosita \& Leonard, 2015). This is because the learning process is only fixated on learning outcomes, so students compete to get optimum results and tend to use learning techniques to memorize subject matter (Putri et al., 2018). The results of study conducted by Sholihah (2016) also shows that in learning, there are almost no collaborative activities carried out by students. Students only focus on the teacher, so students become passive during learning. This passive attitude of students makes students have no experience when studying a material, thus allowing students to save the material delivered by the teacher in the form of short term memory which can later affect learning outcomes (Sari \& Wijayanti, 2017). The lack of collaboration skills among students is also reflected in the results of a study conducted by Kusuma (2018), where in one school, the teacher has trained student collaboration skills by asking students to do assignments in groups. However, there are still students who have not applied their collaboration skills to their full potential. This is reflected in only some students who actively participate, some students just sit quietly or take a walk to see the work of other friends.

The benchmark of collaboration skills among students is supported by the results of study conducted by Mardatillah \& Budiningarti (2018) which states that student collaboration skills in learning can be optimal if students' individualistic attitudes tend to be low, there is interaction between students, and there is tolerance and togetherness between students. To optimize collaboration skills, it is necessary to prepare through education (Sholihah, 2016). Based on this description, this study aims to determine the profile of student collaboration skills at SMA N 07 Surakarta. That way, the teacher can strive for learning to achieve more optimal results.

\section{MATERIALS AND METHODS}

\section{Procedure}

This type of study is a quantitative descriptive study with a survey method. The population of this study were students of grade X, XI, and XII IPA at SMA N 07 Surakarta with the number of students in each grade stratum as many as 204 students of grade X, 205 students of grade XI, and 197 students of grade XII, with a total student population of 600 students.

The research sample used proportional stratified random sampling technique using grade strata which aims to compare the profile of collaboration at each grade level. The research sample was taken as much as $10 \%$ of the total population, namely 60 students with the number of samples taken at each grade level as many as 20 students.

Collaboration skills in this study were measured using a questionnaire developed by Triyatni (2013), which has been tested for validity and reliability. The criteria for collaboration skills are grouped based on the score intervals in Table 1 . 
Table 1. Student Collaboration Ability Levels according to (Riduwan, 2012)

\begin{tabular}{lcc}
\hline Criteria & Value Interval & Level \\
\hline Very High & $81-100$ & Level 5 \\
High & $61-80$ & Level 4 \\
Medium & $41-60$ & Level 3 \\
Low & $21-40$ & Level 2 \\
Very Low & $0-20$ & Level 1 \\
\hline
\end{tabular}

The criteria for collaboration skills are classified based on the $0 \%-20 \%$ interval belonging to level 1 in the very low category, the $21 \%-40 \%$ interval belonging to level 2 with the low category, the $41 \%-60 \%$ interval belonging to level 3 with the moderate category, the interval 61 $\%-80 \%$ belongs to level 4 with the high category, and the $81 \%-100 \%$ interval belongs to level 5 in the very high category. The research instrument used refers to the indicator for measuring the ability of collaboration developed by Crebert, G, et al., (2011) which is presented in Table 2 as follows.

Table 2. Indicators of Student Collaboration Skills (Crebert, et al., 2011)

\begin{tabular}{lll}
\hline Component & Indicator \\
\hline Group Objectives & 1. Understand and agree on group goals \\
Trust and Conflict & 2. Trusting group members and discussing conflict in the group \\
Reactions to Leadership & 3. Discuss differences in groups \\
$\begin{array}{l}\text { Differences } \\
\text { Leadership }\end{array}$ & 4. Participating group members take turns leading the group \\
Controls and Procedures & 5. Have effective group work procedures arranged by group members \\
Use of Resources & 6. Group members know and use available resources \\
Interpersonal Communication & 7. Communication between group members is open and participatory \\
& 8. Group members listen to each other's opinions \\
Listening Skills & 9. The discussion was successful based on listening skills \\
Communication Flow & 10. The group has been steady and agreed in the approach to problem solving \\
Problem Solving or Decision & and decision making \\
Making & 11. Groups have different and creative ways of experimenting \\
Experiment and Creativity & 12. Groups evaluate group work and processes \\
Evaluation &
\end{tabular}

Students fill out the questionnaire by writing the name, grade, and attendance number of the student. Students get an explanation of the procedure for filling out the questionnaire by the researcher. Students then provide an assessment of the collaboration indicators according to the questionnaire format that has been provided.

Each column has only one score, so students must fill in the column completely. Students give a score for each indicator with a breakdown of the score of 5 (very consistent), 4 (consistent), 3 (inconsistent), 2 (rare), and 1 (never). Then, the researcher calculated the score from the questionnaire using the score processing formula as follows.

$$
\text { Score }=\frac{\text { Total Scores Gained }}{\text { Maximum Score }} \times 100 \%
$$

\section{RESULT AND DISCUSSION}

The results of data analysis can be seen that the profile of student collaboration skills at SMA Negeri 07 Surakarta is presented in Figure 1. Based on Figure 1, it can be seen that the profile of science student collaboration skills at SMA N 07 Surakarta in grade $X$ has an very high percentage of $10 \%$, a high percentage of $75 \%$, and 
a moderate percentage of $15 \%$. In grade XI, the percentage of very high scores is $20 \%$, the percentage of high scores is $60 \%$, and the percentage of moderate scores is $20 \%$. In grade XII, the percentage of very high scores is $10 \%$, the percentage of high scores is $80 \%$, and the percentage of moderate values is $10 \%$. The percentage of low and exceptionally low scores at each grade level is $0 \%$.

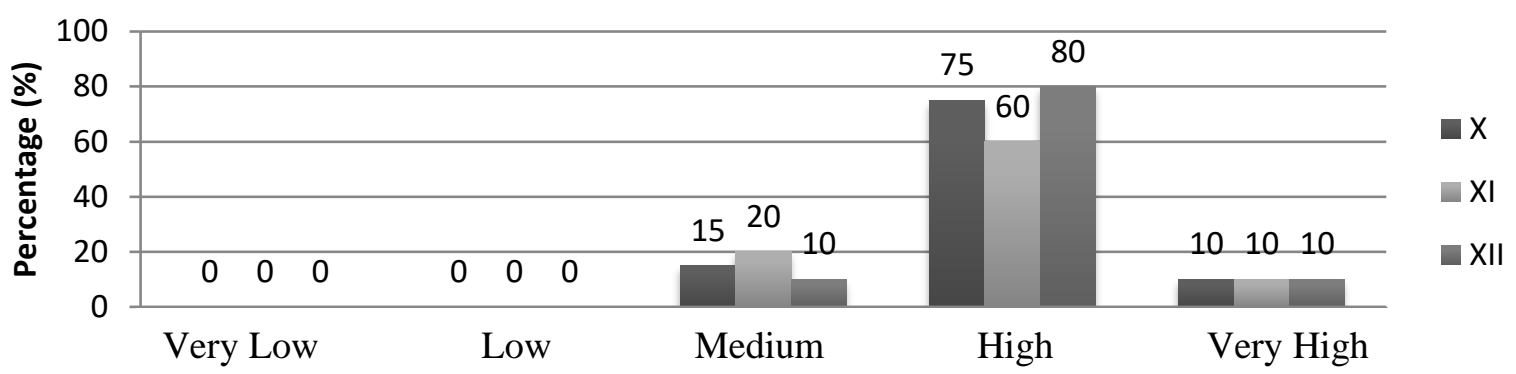

Figure 1. Profile of Collaboration Skills of Science Students at SMAN

The Percentage of Score Per Indicator of Collaboration Skills for Science Students at SMAN 07 Surakarta is presented in Figure 2. Reviewed based on the per-indicator collaboration skills in Figure 2, it is found that the percentage of achievement of the science student collaboration indicators at SMA N 07 Surakarta in grade $\mathrm{X}$ obtained the highest score of collaboration skills, namely the indicator of reaction to differences (indicator 3) of $81 \%$, leadership (indicator 4) at 78\%, and controls and procedures (indicator 5) at $72 \%$. In grade XI, the highest score of collaboration skills on the trust and conflict indicator (indicator) is 68\%, communication flow (indicator 9) is $79 \%$, problem solving (indicator 10) is $79 \%$, and evaluation (indicator 12) is $80 \%$. In grade XII, the highest score for collaboration skills is on the group goal indicator (indicator 1) by $82 \%$, use of resources (indicator 6) is $85 \%$, listening skills (indicator 8) is $85 \%$, interpersonal communication (indicator 7) is $78 \%$, and experiment and creativity (indicator 11) at $79 \%$.

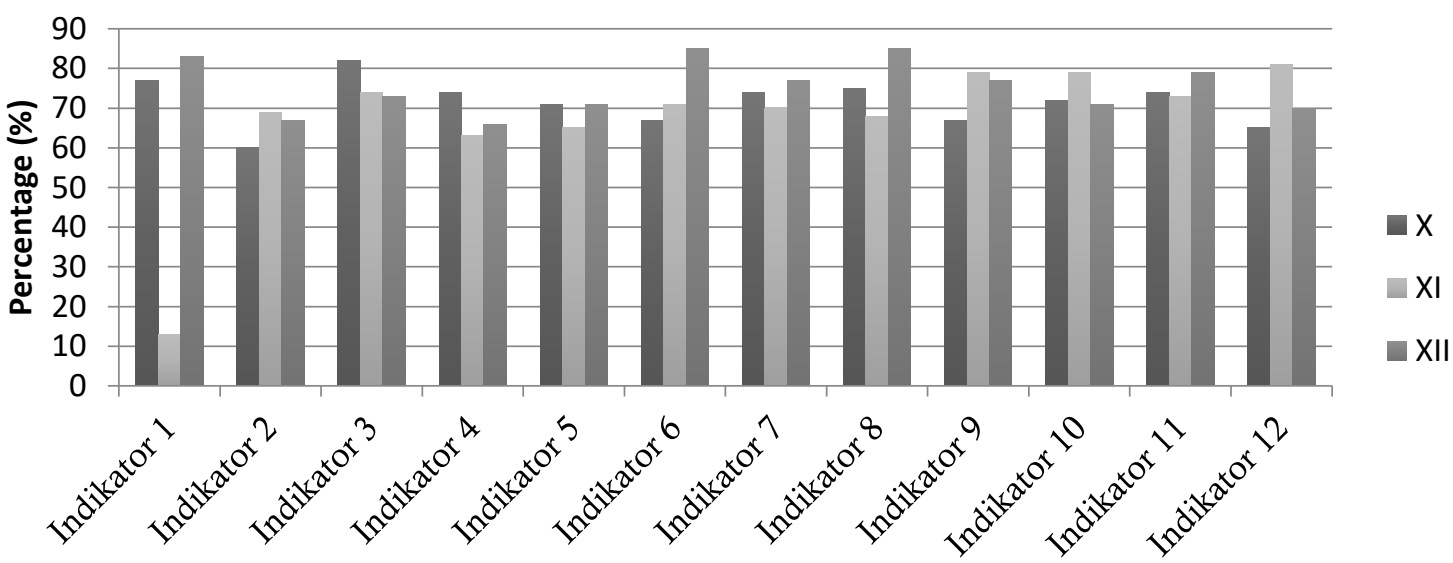

Figure 2. Percentage of Score Per Indicator of Science Students' Collaboration Skills at SMAN 07 Surakarta

Description: Indicator 1: Group Goals; Indicator 2: Trust and Conflict; Indicator 3: Reaction To Difference; Indicator 4: Leadership; Indicator 5: Controls and Procedures; Indicator 6: Use of Resources; Indicator 7: Interpersonal Communication; Indicator 8: Listening Skills; Indicator 9: Communication Flow; Indicator 10: Solution to problem; Indicator 11: Experiment and Creativity; Indicator 12: Evaluation. 
The average results of the calculation of the descriptive profile of the collaboration profile of science students in grade X, XI, and XII in SMA N 07 Surakarta in grade X, XI, and XII are not much different. The average calculation result of the descriptive test of the collaboration profile of science students for grade X was $70.86 \%$, grade XI was $73.99 \%$, and grade XII was $72.32 \%$. Based on these results, it shows that the average collaboration skills of science students in one of the public high schools in Surakarta are at level 4 (61-80\%).

The comparison test of collaboration skill profiles in grade X, XI, and XII was carried out using the one-way ANOVA test with SPSS 23.0. The statistical description of the output of the ANOVA calculation of collaboration skills can be seen in Table 3.

Table 3. Description of ANOVA Calculation Output Statistics

\begin{tabular}{lccccc}
\hline Source & Sum of Squares & df & Mean Square & F & Sig. \\
\hline Between Groups & 99.262 & 2 & 49.631 & .901 & .412 \\
Within Group & 3141.481 & 57 & 55.114 & & \\
\hline Total & 3240.743 & 59 & & & \\
\hline
\end{tabular}

Based on the data in Table 3, the results of the ANOVA test scored an average of 49.631 with $\mathrm{F}_{\text {count }}=0.901$ and a significance value of 0.412 . Therefore, $\mathrm{p}=0.412>0.05$, it can be concluded that there is no difference in collaboration skills between science students of grade X, XI, XII in SMA N 07 Surakarta.

The application of this learning model practically makes students investigators, since they are given the opportunity to observe, analyze and draw conclusions from the practicum activities they do (Handayani et al., 2017). According to Noviyanti, Ristanto, \& Rusdi (2019), the application of the guided discovery model can build learning motivation in students, and this learning motivation is one of the internal factors that determine the success of learning and the level of students' critical thinking. Monroe \& Ernst (2014) bargues that critical thinking is a process that aims to encourage students to solve a problem and be able to make a decision from what they investigate themselves in the learning activities that they participate in. Critical thinking skills are the key for someone to have sensible thinking, gather relevant information efficiently and creatively, and be able to sort various accurate information. (Cheong \& Cheung, 2008).

\section{Discussion}

Student collaboration skills in the classroom can be influenced by the learning model used by the teacher and the student's cognitive level (Khalistyawati \& Muhyadi, 2018). Learning that refers to student-centered makes students more active in exploring their knowledge, so that students can interact and work together with their peers to get a more optimal understanding (Hapsari \& Yonata, 2014). Based on the results of the study, some students who had difficulty understanding the material preferred to ask their group of friends rather than the teacher directly. This way, collaboration can improve students' cognitive abilities and contribute to socialization skills and improve student attitudes (Hapsari \& Yonata, 2014).

Learning models that are able to train collaboration skills can be used as cooperative learning models. The cooperative learning model divides students into small groups to discuss the completion of the given structural assignments (Rosita \& Leonard, 2015). The learning process requires students to actively exchange information with each other, for example by means of discussion (Nurnawati, et al., 2012). The cooperative learning model focuses on improving the students' cognitive and affective through 
collaboration skills. Collaboration criteria are considered good if the percentage of collaboration indicators is more than 50\%. If the percentage of collaboration indicators is less than $50 \%$, it is considered somewhat poor (Rudhia, 2007).

The results showed that the collaboration skills of science students at SMA N 07 Surakarta were in the good category. All indicator components have a percentage value of more than $50 \%$ according to the existing indicators. Based on the results of the research on the collaboration skills profile of science students at SMA N 07 Surakarta, it can be seen that the average value of collaboration in grade $\mathrm{X}$ is $70.86 \%$, grade $\mathrm{XI}$ is $73.99 \%$, and $72.32 \%$. The results of this study indicate that the collaboration skills of students in both grade X IPA, XI IPA, and grade XII IPA are in the high category because all are in the range of $61 \%-80 \%$.

The high profile of collaboration skills among science students for grade X, XI, and XII at SMA N 07 Surakarta is because the learning model used by the teacher is able to facilitate and encourage students to be more active in the distribution of tasks during discussions. The cohesiveness of each member of the group builds positive collaboration (Purwaningtyastuti, 2012). There are collaborative interactions between students to complete a task/project, share learning resources, and engage in discussions to broaden each other's knowledge.

Positive collaboration can be established when students can achieve their goals if and only if there is collaboration with other students to achieve a common goal (Nurnawati, et al., 2012). Based on the data obtained and the ANOVA calculation results, the students' grade does not have a significant effect on the profile of collaboration skills in SMA N 07 Surakarta. This is in accordance with the theory put forward by Kitchen \& McDougall (1999) which states that collaboration skills are not significantly affected by age, gender, grade level, and computer literacy. Student collaboration skills are formed on the basis of students' concern for each other. Students who care about the circumstances around them tend to have high collaboration skills values. Several factors that can improve collaboration skills among students include solidarity, equal distribution of work load, and the existence of relevant communications between students (Gaddis, et al., 2000).

Within the scope of school, student collaboration skills can be reflected in activities in the classroom such as discussions conducted to solve a problem, structured assignments given in groups, as well as activities outside the classroom, such as student organization and extracurricular activities.

\section{CONCLUSION}

The results of this study indicate that the profile of the collaboration skills of science students at SMA Negeri 07 Surakarta with a total sample of 60 students taken from grades X, XI, and XII is high (high collaboration skills if it reaches a value range of 61-80\%). ANOVA test results show that $\mathrm{p} 0.412>0.05$ so it can be concluded that there is no difference in collaboration skills between grade X, XI, and XII IPA in SMA N 07 Surakarta.

\section{REFERENCES}

Crebert, G., et al. (2011). Problem Solving Skills Toolkit 2nd Edition. Quensland: Griffit University. Gaddis, B., Napierkowski, H., Guzman, N., \& Muth, R. (2000). A Comparison of Collaborative Learning and Audience Awareness in Two Computer-Mediated Writing Environments. Prosiding of National Convention of the Association for Educational Communications and Technology, 1(2).

Hamid, \& Sholeh, M. (2011). Metode Edutainment. Jogjakarta: Diva Press.

Hapsari, N. S., \& Yonata, B. (2014). Keterampilan Kerjasama saat Diskusi Kelompok Siswa Kelas XI IPA pada Materi Asam Basa melalui Penerapan Model Pembelajaran Kooperatif di SMA Kemala Bhayangkari 1 Surabaya. Unesa Journal of 
Chemical Education, 3(2), 181-188.

Indy, R., Waani, F. J., \& Kandowangko, N. (2019). Peran Pendidikan dalam Proses Perubahan Sosial di Desa Tumaluntung Kecamatan Kauditan Kabupaten Minahasa Utara. Holistik: Journal of Social and Culture, 12(4), 1-21.

Khalistyawati, M., \& Muhyadi. (2018). Pengaruh Model STAD dan Jigsaw terhadap Karakter Kerja Sama, Kemampuan Berpikir Kritis, dan Hasil Belajar Kognitif. Jurnal Pendidikan Karakter, 8(2), 187-205.

Khoiriah, D. S. (2016). Pengaruh Model Pembelajaran Kooperatif Tipe Team Game Tournament (Tgt) terhadap Pembentukan Nilai-Nilai Kerjasama dalam Pembelajaran Permainan Hoki. Jurnal Pendidikan Jasmani Dan Olahraga, 1(1), 27. http://doi.org/10.17509/jpjo.v1i1.3661

Kitchen, D., \& McDougall, D. (1999). Collaborative Learning on the Internet. Journal of Educational Technology Systems, 27(3), 245-258. http://doi.org/10.2190/5h41-k8vu-nrfj-pdyk

Kusuma, A. W. (2018). Meningkatkan Kerjasama Siswa dengan Metode Jigsaw dalam Bimbingan Klasikal. Konselor, 7(1), 26-30. http://doi.org/10.24036/02018718458-0-00

Mardatillah, F., \& Budiningarti, H. (2018). Penerapan Model Pembelajaran Kooperatif Tipe Stad Untuk Melatihkan Kerjasama Peserta Didik. Inovasi Pendidikan Fisika, 7(3), 385-389.

Nurnawati, E., Yulianti, D., \& Susanto, H. (2012). Pembelajaran Kooperatif Tipe Jigsaw dalam Mata Kuliah Teknologi Air dan Pengolahan Limbah Industri. Jurnal Cakrawala Pendidikan, 1(1). http://doi.org/10.21831/cp.v0i1.1471

Purwaningtyastuti. (2012). Kohesivitas Kelompok Ditinjau dari Komitmen Terhadap Organisasi dan Kelompok Pekerjaan. Kajian Ilmiah Psikologi, 1(2), 179-182.

Putri, A. R., Maison, \& Darmaji. (2018). Kerjasama dan Kekompakan Siswa dalam Pembelajaran Fisika di Kelas XII MIPA SMA N 03 Kota Jambi. Edufisika: Jurnal Pendidikan Fisika, 3(2).

Riduwan. (2012). Belajar Mudah Penelitian. Bandung: Alfabeta.

Rosita, I., \& Leonard. (2015). Meningkatkan Kerja Sama Siswa Melalui Pembelajaran Kooperatif Tipe Think Pair Share. Formatif: Jurnal Ilmiah Pendidikan MIPA, 3(1), 1-10. http://doi.org/10.30998/formatif.v3i1.108

Rudhia, A. (2007). Kualitas Kerjasama Siswa dalam Pembelajaran Menggunakan Model Pembelajaran Kooperatif Tipe Group Investigation pada Materi Pokok Sistem Pencernaan Makanan. Bandar Lampung: Universitas Lampung Press.

Sari, S., \& Wijayanti, A. (2017). Talking Stick: Hasil Belajar IPA Dan Kemampuan Kerjasama Siswa. Wacana Akademika: Majalah Ilmiah Kependidikan, 1(2), 175-184. http://doi.org/10.30738/wa.v1i2.1642

Sholihah. (2016). Profil Kemampuan Kerjasama Siswa dalam Pembelajaran IPA. Lampung: Universitas Lampung Press.

Triyatni. (2013). Upaya Meningkatkan Keterampilan Kerjasama Kelompok Siswa melalui Penggunaan Model Pembelajaran Group to Group Exchange di Kelas VII E SMP Negeri 22 Surakarta. Surakarta: UNS Press.

Turiman, P., Omar, J., Daud, A. M., \& Osman, K. (2012). Fostering the 21st Century Skills through Scientific Literacy and Science Process Skills. Procedia - Social and Behavioral Sciences, 59, 110-116. http://doi.org/10.1016/j.sbspro.2012.09.253

Wijaya, E. Y., Sudjimat, D. A., \& Nyoto, A. (2016). Transformasi Pendidikan Abad 21 Sebagai Tuntutan. Prosiding Seminar Nasional Pendidikan Matematika, 1, 263-278. 